\title{
Carbon balance of a partially harvested mixed conifer forest following mountain pine beetle attack and its comparison to a clear-cut
}

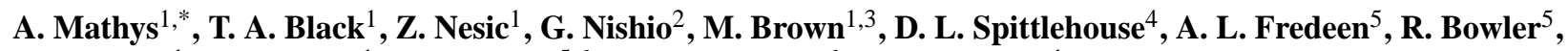 \\ R. S. Jassal ${ }^{1}$, N. J. Grant ${ }^{1}$, P. J. Burton ${ }^{5,6}$, J. A. Trofymow ${ }^{6}$, and G. Meyer ${ }^{1}$ \\ ${ }^{1}$ Faculty of Land and Food Systems, University of British Columbia, Vancouver, British Columbia, V6T 1Z4, Canada \\ ${ }^{2}$ FPInnovations, Vancouver, British Columbia, V6T 1W5, Canada \\ ${ }^{3}$ Department of Geography and Environmental Studies, Carleton University, Ottawa, Ontario, K1S 5B6, Canada \\ ${ }^{4}$ Ministry of Forests, Lands and Natural Resource Operations, Victoria, British Columbia, V8W 9C2, Canada \\ ${ }^{5}$ Ecosystem Science and Management Program, University of Northern British Columbia, Prince George, British Columbia, \\ V2N 4Z9, Canada \\ ${ }^{6}$ Pacific Forestry Centre, Canadian Forest Service, Victoria, British Columbia, V2N 4Z9, Canada \\ *now at: Department of Forest Resource Management, University of British Columbia, Vancouver, British Columbia, \\ V6T 1Z4, Canada
}

Correspondence to: A. Mathys (amathys@alumni.ubc.ca)

Received: 30 January 2013 - Published in Biogeosciences Discuss.: 11 March 2013

Revised: 27 June 2013 - Accepted: 2 July 2013 - Published: 15 August 2013

\begin{abstract}
The recent mountain pine beetle (MPB) outbreak has had an impact on the carbon (C) cycling of lodgepole pine forests in British Columbia. This study examines how partial harvesting as a forest management response to MPB infestation affects the net ecosystem production (NEP) of a mixed conifer forest (MPB-09) in Interior BC. MPB-09 is a 70-year-old stand that was partially harvested in 2009 after it had been attacked by MPB. Using the eddy-covariance technique, the $\mathrm{C}$ dynamics of the stand were studied over two years and compared to an adjacent clear-cut (MPB-09C) over the summertime. The annual NEP at MPB-09 increased from $-108 \mathrm{~g} \mathrm{C} \mathrm{m}^{-2}$ in 2010 to $-57 \mathrm{~g} \mathrm{C} \mathrm{m}^{-2}$ in 2011 . The increase of NEP was due to the associated increase in annual gross ecosystem photosynthesis (GEP) from $812 \mathrm{~g} \mathrm{C} \mathrm{m}^{-2}$ in 2010 to $954 \mathrm{~g} \mathrm{C} \mathrm{m}^{-2}$ in 2011, exceeding the increase in annual respiration $\left(R_{\mathrm{e}}\right)$ from $920 \mathrm{~g} \mathrm{C} \mathrm{m}^{-2}$ to $1011 \mathrm{~g} \mathrm{C} \mathrm{m}^{-2}$ during the two years. During the four month period between June and September 2010, NEP at MPB-09C was $-103 \mathrm{~g} \mathrm{C} \mathrm{m}^{-2}$, indicating high $\mathrm{C}$ losses in the clear-cut. MPB-09 was a $\mathrm{C}$ sink during the growing season of both years, increasing from $9 \mathrm{~g} \mathrm{C} \mathrm{m}^{-2}$ in 2010 to $47 \mathrm{~g} \mathrm{C} \mathrm{m}^{-2}$ in 2011 . The increase of NEP in the partially harvested stand amounted to a recovery
\end{abstract}

corresponding to a $26 \%$ increase in the maximum assimilation rate in the second year. This study shows that retaining the healthy residual forest can result in higher $\mathrm{C}$ sequestration of MPB-attacked stands compared to clear-cut harvesting.

\section{Introduction}

Forest management practices in response to insect outbreaks have an impact on the forest carbon (C) balance. In British Columbia (BC) the mountain pine beetle (MPB) outbreak began in the late 1990s and has affected a total area of 18.1 million ha of pine-leading stands with a recent expansion into Alberta (B.C. Ministry of Forests, Lands and Natural Resource Operations, 2012). The unprecedented scale of the outbreak has killed 710 million $\mathrm{m}^{3}$ or $53 \%$ of the merchantable pine volume in BC from 1999 to 2011 (Walton, 2012). Reasons for the expansion of the outbreak include climate change, which has been attributed to increasing atmospheric concentrations of carbon dioxide $\left(\mathrm{CO}_{2}\right)$ and other greenhouse gases on a global scale (IPCC, 2007). 
In Northern BC, minimum air temperature in the winter has increased by $3.5^{\circ} \mathrm{C}$ in the past century (Moore et al., 2010; Rodenhuis et al., 2009) allowing the beetle to survive through the winter to the following year (Carroll et al., 2006; Safranyik and Wilson, 2006). Furthermore, fire suppression in $\mathrm{BC}$ has led to a large abundance of even-aged mature lodgepole pine stands that provide a favorable habitat for the MPB (Taylor and Carroll, 2004). In response to the outbreak, the provincial government increased the annual allowable cut by 15 million $\mathrm{m}^{3}$ to about 67 million $\mathrm{m}^{3}$ per year in Interior BC (Bogdanski et al., 2011; Snetsinger, 2011). The most common forest management strategy in $\mathrm{BC}$ is to clear-cut the entire stand. As an alternative practice, partial harvesting can be undertaken to reduce the disturbance of the forest. This can help maintain the forest's role of providing environmental services such as sustaining energy, water and nutrient cycles, providing habitat for wildlife, and reducing runoff to rivers and streams. Furthermore, protecting the non-pine secondary structure provides opportunities for mid-term timber harvest that can help reduce the predicted shortage in 15-50 yr (Nishio, 2010). Coates et al. (2006) define secondary structure as all the non-pine canopy and subcanopy trees as well as seedlings and saplings that survive the beetle outbreak. Accordingly, the stands that contain healthy residual vegetation can already constitute the next generation of forest cover without having to be planted (Burton, 2006; Coates et al., 2006). About 20-30\% of pine-leading stands in north-central BC have been found to have abundant secondary structure that can contribute to the mid-term timber supply (Coates et al., 2006). Local efforts in the Prince George region of $\mathrm{BC}$ have attempted to minimize the disturbance on forest soils and vegetation cover through partial harvest operations and improving the sustainability of forest management practices (Nishio, 2010).

Disturbances such as insect infestation, harvesting and fire have been shown to shift Canada's forests from $\mathrm{C}$ sinks to $\mathrm{C}$ sources (Amiro et al., 2010; Kurz et al., 2008). Currently, there is limited information available on how post MPBoutbreak disturbance affects stand C dynamics. Monitoring forest net ecosystem production (NEP) over the long term has been recommended to help provide a better understanding of how management decisions on insect control affect forest productivity (Amiro et al., 2010; Kurz and Apps, 1999). NEP is the balance of $\mathrm{C}$ uptake through gross ecosystem photosynthesis (GEP) and C loss resulting from ecosystem respiration $\left(R_{\mathrm{e}}\right)$ over a period of time and is an indicator of whether the stand is sequestering or losing $\mathrm{C}$ to the atmosphere. It is obtained as -NEE, the net ecosystem exchange between the land surface and atmosphere, and can be measured using the eddy-covariance (EC) technique (Baldocchi, 2003).

Studies have recently been examining the effects of the MPB on the $\mathrm{C}$ dynamics of forests that are left to recover naturally (Brown et al., 2012; Edburg et al., 2011; Kurz et al., 2008). EC measurements were made in two MPB-attacked lodgepole pine stands located approximately 20 and $120 \mathrm{~km}$ north of the current study sites (Brown et al., 2010; Brown et al., 2012). The recovery of the two stands occurred faster than previously assumed (Kurz et al., 2008) with C neutrality reached within 3 to $5 \mathrm{yr}$ following the beetle attack (Brown et al., 2012). This was attributed to the compensatory $C$ uptake of the surviving trees and understory vegetation (Bowler et al., 2012), increased light penetration and reduced competition for soil nutrients and water due to tree mortality. Furthermore, growing season $\mathrm{C}$ flux measurements of lodgepole pine stands that were clear-cut harvested were found to remain annual $\mathrm{C}$ sources for at least $10 \mathrm{yr}$ (Brown et al., 2010). A similar general outcome was reported by Edburg et al. (2011), who used the Community Land Model to determine how long-term $\mathrm{C}$ fluxes are affected after MPB outbreaks, with particular outcomes depending on the severity of the outbreak and the snagfall transfer rate (the fall and transfer to coarse woody debris). They predicted a secondary decrease in NEP once the dead standing trees fall, increasing heterotrophic respiration $\left(R_{\mathrm{h}}\right)$ due to a greater amount of coarse woody debris available to decompose. Edburg et al. (2011) also simulated NEP responses to clear-cut harvesting of beetle-killed trees and found the harvested stands to be an annual $\mathrm{C}$ source for $25 \mathrm{yr}$ before returning to a $\mathrm{C}$ sink. Overall they found management decisions to have a major impact on the $\mathrm{C}$ balance in post-outbreak stands. Kurz et al. (2008) used the $C$ budget model of the Canadian Forest Sector (CBM-CFS3) to determine the cumulative impact of the MPB outbreak in BC's forests. They predicted a loss of $270 \mathrm{Tg}$ C over a $374000 \mathrm{~km}^{2}$ forest area from 2000 to 2020 with the removal of beetle-killed and healthy trees contributing an additional loss of $50 \mathrm{Tg} \mathrm{C}$ during salvage harvest operations.

There is a need to understand how forest management practices affect the $\mathrm{C}$ exchange processes of forests attacked by MPB. This study determines the impact of partial harvesting on the NEP of a 70-year-old stand using the EC technique and compares the summertime $\mathrm{C}$ balance of the partially harvested stand with a nearby clear-cut, harvested at the same time. It is hypothesized that partial harvesting will lower $\mathrm{CO}_{2}$ emissions of the forest compared to clear-cut harvesting. Retaining biomass can maintain the photosynthetic capacity resulting in continued $\mathrm{C}$ sequestration in the residual stand. Furthermore, a reduced amount of dead roots, coarse woody debris and litter are left behind to decompose and contribute to $R_{\mathrm{h}}$ compared to a clear-cut. Partial harvesting helps provide a continuous supply of litter fall, which can shade the soil surface and reduce soil temperature and hence $R_{\mathrm{h}}$, which increases with soil temperature (Taylor et al., 2008). This choice of harvesting practice can increase the forest's capability for $\mathrm{C}$ uptake, while at the same time preserve habitats for ecosystem biodiversity and maintain the future economic viability of the forest to meet society's needs by providing a mid-term timber supply within 20-40 yr, compared to approximately $80 \mathrm{yr}$ required for a clear-cut. The objectives of this study were (1) to measure the annual clear-cut NEP of 
a partially harvested mixed-conifer stand following an MPB attack, (2) to determine GEP and $R_{\mathrm{e}}$ and how they are affected by environmental factors, (3) to compare NEP, GEP and $R_{\mathrm{e}}$ of the partially harvested stand with values from a nearby clear-cut.

\section{Methods}

\subsection{Site description}

The study site (MPB-09) was located on generally level ground in the Interior of BC near Summit Lake, $46 \mathrm{~km}$ north of Prince George (Table 1). Following MPB attacks in 2005 and 2006, the 70-year-old stand was partially harvested in a 40 ha cutblock (Nishio, 2010). Harvesting operations occurred from February to March 2009. The beetle-killed lodgepole pine trees were removed along manually selected trails, and the non-pine tree species (i.e. secondary structure) were retained (Fig. 1). In the process, the trees were felled by a feller-buncher and then skidded to roadside landings. This technique reduces the impact of soil compaction by restricting the movement of the logging equipment to the designated trails. Furthermore, deep snow conditions in the winter protected $13-30 \%$ more understory than when harvesting occurred after snow melt (Nishio, 2009). The harvested volume of the partially harvested stand was $152 \mathrm{~m}^{3} \mathrm{ha}^{-1}$ with a total volume of $6022 \mathrm{~m}^{3}$ (Nishio, 2010). He found that overstory basal area was reduced from $39.6 \mathrm{~m}^{2} \mathrm{ha}^{-1}$ prior to harvesting to $7.6 \mathrm{~m}^{2} \mathrm{ha}^{-1}$ after harvesting in 2009 . The residual canopy was composed of a combination of black spruce (Picea mariana), hybrid white spruce (Picea engelmannii $\times$ glauca) and subalpine fir (Abies lasiocarpa) trees. The understory consisted of small tree and shrub species, including pink spiraea (Spiraea douglasii ssp. menziesii), bearberry honeysuckle (Lonicera involucrata) and willow (Salix spp.). In May 2010, the stand was replanted with tree seedlings consisting of $57 \%$ lodgepole pine and $43 \%$ hybrid white spruce at a planting density of 1370 stems ha $^{-1}$ within both the harvested trails and retention areas. Soil, vegetation and overstory characteristics were also measured in 2010 at MPB-09 on three National Forest Inventory (NFI, 2008) ground plots within $50 \mathrm{~m}$ of the flux tower. Measurements indicated that stand density and overstory basal area were $308 \pm 113$ (mean and standard deviation) stems ha ${ }^{-1}$ and $5.6 \pm 1.0 \mathrm{~m}^{2} \mathrm{ha}^{-1}$, respectively. The groundcover consisted of mosses, grasses and ferns. Coarse woody debris, plant litter and exposed soil were also found on the forest floor as a result of the harvesting activities. The soil is classified as an Orthic Gray Luvisol with a silty clay loam texture derived from glaciolacustrine deposits (P. Sanborn, personal communication, 2012). The surface organic layer (LFH) had an average thickness of $8 \mathrm{~cm}$. Site characteristics are summarized in Table 1. Adjacent to MPB-09 was a 4.2 ha clear-cut (MPB-09C), which had the same understory composition and soil type as in
Table 1. Site description for MPB-09 after partial harvesting. Values in parentheses indicate standard deviations $( \pm$ S.D.) from the mean.

\begin{tabular}{|c|c|}
\hline & MPB-09 \\
\hline Stand age (yr) & $\sim 70( \pm 10)^{\mathrm{a}}$ \\
\hline Site location & $\begin{array}{l}54^{\circ} 13^{\prime} 25.4^{\prime \prime} \mathrm{N} \\
122^{\circ} 36^{\prime} 53.5^{\prime \prime} \mathrm{W}\end{array}$ \\
\hline Elevation $(\mathrm{m})$ & 680 \\
\hline Canopy height (m) & $\sim 16( \pm 4)$ \\
\hline Stand density $\left(\right.$ stems $\left.\mathrm{ha}^{-1}\right)$ & $435^{\mathrm{b}}$ \\
\hline Overstory basal area $\left(\mathrm{m}^{2} \mathrm{ha}^{-1}\right)$ & $7.6^{\mathrm{c}}$ \\
\hline Dominant tree species & $\begin{array}{l}\text { Picea mariana, Picea } \\
\text { engelmannii } \times \text { glauca, } \\
\text { Abies lasiocarpa }\end{array}$ \\
\hline Understory vegetation & $\begin{array}{l}\text { Spiraea douglasii, } \\
\text { Lonicera involucrata, } \\
\text { Salix spp. }\end{array}$ \\
\hline Overstory LAI $\left(\mathrm{m}^{2} \mathrm{~m}^{-2}\right)$ & 1.3 \\
\hline Soil classification & Orthic Gray Luvisol $^{\mathrm{d}}$ \\
\hline Litter-fibric-humus (LFH) $\mathrm{C}\left(\mathrm{kg} \mathrm{ha}^{-1}\right)$ & $30.6-42.6$ \\
\hline Average $(n=3)$ LFH thickness $(\mathrm{cm})$ & $8( \pm 4)$ \\
\hline Mineral soil C $(0-55 \mathrm{~cm})\left(\mathrm{kg} \mathrm{ha}^{-1}\right)$ & $75.6-158.9$ \\
\hline Fine mineral soil bulk density $\left(\mathrm{kg} \mathrm{m}^{-3}\right)$ & $1247-1495^{\mathrm{e}}$ \\
\hline Soil texture & Silty clay loam \\
\hline
\end{tabular}

${ }^{\text {a }}$ Age determined from 52 samples.

b Values for the tower footprint area.

${ }^{c}$ Value for the full partial cut block (Nishio, 2010).

d P. Sanborn (UNBC, personal communication, 2012).

e Volumetric coarse fraction was $<1 \%$.

the partially harvested stand (Nishio, 2010). It lies approximately $1 \mathrm{~km}$ north of MPB-09 and was harvested at the same time. The harvested volume of the clear-cut was $474 \mathrm{~m}^{3}$ with a smaller average tree size than MPB-09. It was replanted with the same seedlings as the partially harvested stand in the spring of 2010. Both MPB-09 and MPB-09C are in the SubBoreal Spruce Biogeoclimatic Zone (SBSmk1) (Meidinger and Pojar, 1991).

\subsection{Flux and climate measurements}

Eddy-covariance and climate measurements have been continuously made since October 2009 at MPB-09. Instruments were mounted on a scaffold tower that was $2.1 \mathrm{~m}$ long, $1.5 \mathrm{~m}$ wide and $32 \mathrm{~m}$ high. An ultrasonic anemometer (model CSAT3, Campbell Scientific Inc. (CSI), Logan, Utah, USA) was installed at a height of $26 \mathrm{~m}$ to measure components of the wind vector and air temperature, along with an open-path infrared gas analyzer (IRGA, model LI-7500, LI-COR Inc., Lincoln, Nebraska, USA) to measure $\mathrm{CO}_{2}$ and water vapor densities at a frequency of $10 \mathrm{~Hz}$. The tower was located near the SE edge of the cut block with the EC sensors mounted on the west side of the tower. This ensured that the flux footprint lay mainly within the partially harvested stand since the prevailing wind direction was from the NW to SW. Instrument calibrations were performed in the laboratory prior to 


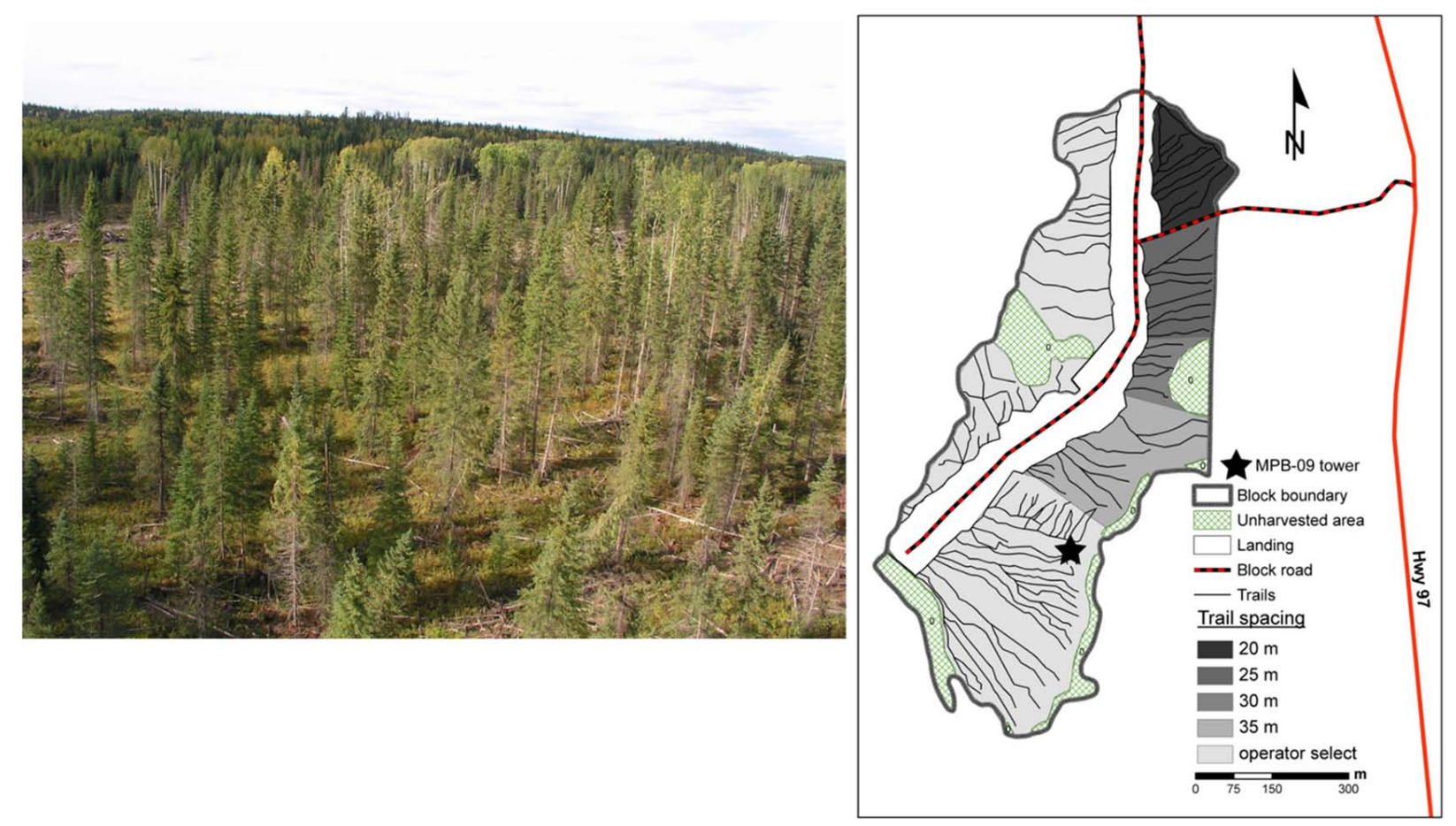

Fig. 1. Photograph and schematic diagram of the partially harvested stand with locations of the MPB-09 flux tower and harvesting trails. The clear-cut, MPB-09C, is located $1 \mathrm{~km}$ north of MPB-09. Source: Nishio (2010).

installation at the site. The IRGA was replaced in 2011. The calibration of the replaced IRGA was checked in the laboratory and found to show little change in both the sensitivity and offset. Climate measurements included air temperature and relative humidity (model HMP45C, Vaisala Oyj, Helsinki, Finland). Comparison of calculated specific humidity from the IRGA water vapor density with the HMP45C showed that the measurements were in good agreement during the two years of the study. Downwelling and upwelling shortwave radiation and longwave radiation were measured with a net radiometer (model CNR1, Kipp and Zonen B.V., Delft, the Netherlands) above the canopy at the $30 \mathrm{~m}$ height and below the canopy upwelling shortwave radiation was measured with a Black \& White Pyranometer (model 8-48, Eppley Laboratory Inc., Newport, Rhode Island, USA) at the $3 \mathrm{~m}$ height. Quantum sensors (model LI-190AS, LI-COR Inc.) were used to measure downwelling and upwelling photosynthetically active radiation (PAR) above the canopy as well as below-canopy downwelling PAR. Rainfall was measured with a tipping-bucket rain gauge (model 52203 R.M. Young Co., Traverse City, MI) at the $5 \mathrm{~m}$ height, providing an adequate angle of catch in an open area where interception by the canopy was negligible. Wind speed was recorded with a propeller-vane anemometer (model 05103 R.M. Young Co.). Two soil profiles were established to measure soil temperature at depths of $3,10,20,50$ and $100 \mathrm{~cm}$ using soil thermistors (model ST100, Apogee Instruments Inc. Logan, Utah,
USA). Volumetric soil water content was also measured in two soil profiles at 3,20,50 and $100 \mathrm{~cm}$ depths with water content reflectometers (model CS615 and CS616, CSI). Soil heat flux was measured at the $3 \mathrm{~cm}$ depth with 4 soil heat flux plates that were homemade (using Peltier coolers) and calibrated at UBC, and was corrected for heat storage in the $3 \mathrm{~cm}$ soil surface layer. The surface temperature of the forest floor was measured with a downward-facing infrared radiometer (model Apogee SI-111, CSI) and snow depth with an acoustic distance sensor (model SR50A, CSI) mounted at $3.6 \mathrm{~m}$ height. Snowfall was estimated by converting changes in snow depth to snow-water equivalent using a density of $100 \mathrm{~kg} \mathrm{~m}^{-3}$. The climate measurements were sampled at a rate of $0.5 \mathrm{~Hz}$. Climate and flux data were recorded on two data loggers (model CR1000, CSI). The half-hour averages and covariances used to derive the turbulent fluxes were calculated and sent to UBC Biometeorology Laboratory via cell-phone connection on a daily basis. A compact flash card stored the high frequency data and was replaced every 2-4 weeks. The system was powered by three $100 \mathrm{~W}$ solar panels and an $800 \mathrm{Ah}$ battery unit as described in Brown et al. (2010).

The forest leaf area index (LAI) was measured in 2011 using a LI-COR Plant Canopy Analyzer (model LAI- 2000, LI-COR Inc.) and a Tracing Radiation and Architecture of Canopies (TRAC) system (Third Wave Engineering, Nepean, 
Ontario, Canada) following the procedure outlined by Chen et al. (2006).

At MPB-09C, EC measurements were made during the summer of 2010 (10 June-22 September), using the same instruments as above but mounted on a tripod at $2.2 \mathrm{~m}$ above the ground. The EC and climate data were recorded on a data logger (model CR5000, CSI) and the system was powered by a $100 \mathrm{~W}$ solar panel.

\subsection{Data analysis and quality control}

\subsubsection{Flux calculations}

Fluxes of $\mathrm{CO}_{2}\left(F_{\mathrm{c}}\right)$ and water vapor (i.e., evapotranspiration) $(E)$ were calculated by multiplying the dry air density by the covariances of the vertical wind speed $(w)$ and the $\mathrm{CO}_{2}$ and water vapor mixing ratios, respectively. The covariances were block-averaged in $30 \mathrm{~min}$ intervals with no detrending applied. Three coordinate rotations were performed on each half-hour average to align the vertical wind velocity measurement normal to the mean wind streamlines, bringing the mean vertical $(\bar{w})$ and lateral $(\bar{v})$ wind vector components as well as the covariance between these components $\left(\overline{w^{\prime} v^{\prime}}\right)$ to zero (Tanner and Thurtell, 1969). Half-hour averaged data points were removed when instruments malfunctioned during events such as snow, rain and frost by setting limits of average, minimum, maximum and standard deviations on $\mathrm{CO}_{2}$ and water vapor fluxes. The data were also visually inspected and the high frequency data were examined before removing data points that deviated from the general course of the time series. NEE was calculated using:

$\mathrm{NEE}=F_{\mathrm{c}}+S_{\mathrm{t}}$,

where $S_{\mathrm{t}}$ is the rate of change of $\mathrm{CO}_{2}$ storage in the air column below the EC system. The storage term was calculated using the difference between the mean mixing ratio for the following and previous half hour at EC sensor height (Morgenstern et al., 2004). To deal with the questionable nighttime flux measurements in calm conditions, data were rejected when the friction velocity $\left(u_{*}\right)$ fell below a threshold $\left(u_{* \mathrm{th}}\right)$ of $0.2 \mathrm{~m} \mathrm{~s}^{-1}$. This value was determined by sorting increasing nighttime NEE according to $u_{*}$ into bin averages of 100 data points each and identifying at what $u_{*}$ value NEE no longer increased. Flux measurements were also removed when the wind direction was from NE to SE $\left(45-135^{\circ}\right)$, as the footprint extended outside the partially harvested stand. This also removed data points corresponding to when the wind blew through the tower before reaching the EC system that was oriented in a westward direction.

The use of open-path IRGAs during wintertime has been found to result in unexpected $\mathrm{CO}_{2}$ uptake (Lafleur and Humphreys, 2007; Burba et al., 2008; Bonneville et al., 2008). Burba et al. (2008) attributed this to the heat generation inside the IRGA, leading to a sensible heat flux inside the open-path array which affects the $\mathrm{CO}_{2}$ density, and proposed applying a sensor-heating correction. There is a lack of consensus on the issue because some comparisons of flux measurements using open- and closed-path analyzers (Wohlfahrt et al., 2008; Bowling et al., 2010) have shown much better agreement without the sensor-heating correction. Using an LI-7500, Amiro (2010) also found apparent ecosystem uptake of $\mathrm{CO}_{2}$ in frozen soil conditions when a small respiratory flux was expected and they found that removing such data followed by gap-filling worked just as well. Burba et al. (2008) found that sensor heating decreased for wind speeds exceeding 6-8 $\mathrm{m} \mathrm{s}^{-1}$. Consequently, we discarded all wintertime fluxes when NEE $<0$ and daytime winter data when wind speed $<4 \mathrm{~m} \mathrm{~s}^{-1}$ as described in Brown et al. (2010). Although removing only negative NEE values in wintertime would have introduced a bias towards greater $\mathrm{CO}_{2}$ loss, sensor heating of the LI-7500 would have caused some reduction in measured $F_{\mathrm{c}}$ (i.e., $R_{\mathrm{e}}$ ) during winter months.

Missing data during the rest of the year were gap-filled according to standard methods developed by the Fluxnet Canada Research Network (Barr et al., 2004). Respiration was modeled using a logistic equation relating nighttime $R_{\mathrm{e}}$ to soil temperature at the $3 \mathrm{~cm}$ depth:

$R_{\mathrm{e}}=\frac{r_{1}}{1+\exp \left[r_{2}\left(r_{3}-T_{\mathrm{s}}\right)\right]}$,

where $r_{1}, r_{2}$ and $r_{3}$ are model-fitted empirical constants. Equation (2) was used to gap-fill nighttime data and calculate daytime half-hourly $R_{\mathrm{e}}$ (the latter using daytime $T_{\mathrm{S}}$ ). Halfhourly GEP values were calculated by adding measured daytime NEP to modeled daytime $R_{\mathrm{e}}$. Gaps in GEP were filled using the rectangular hyperbolic Michaelis-Menten relationship with $\operatorname{PAR}(Q)$ :

$\mathrm{GEP}=\frac{\alpha Q A_{\max }}{\alpha Q+A_{\max }}$,

where $\alpha$ is the quantum yield and $A_{\max }$ is the photosynthetic capacity. Annual relationships were first used to model $R_{\mathrm{e}}$ and GEP values using Eqs. (2) and (3), which then were adjusted by including an additional parameter. This timevarying parameter was used to make the modeled mean value equal to the mean measured value within a moving window interval, which was 100 points wide and moved at an increment of 20 points at a time (Barr et al., 2004). The gapfilling procedure was slightly altered according to Brown et al. (2010) by not applying the moving window during the wintertime when large data gaps occurred. When high frequency data from the flash card were lost due to technical issues, fluxes were calculated by applying the WPL equation (Webb et al., 1980) to the half-hour averaged covariances sent from the data logger on a daily basis.

\subsubsection{Uncertainty analysis}

Uncertainties exist in the annual totals of NEP, GEP and $R_{\mathrm{e}}$, which are caused by random and systematic errors. The 
primary systematic error, which is caused by occurrence of low wind speeds at night, was dealt with by applying the $u_{*}$ threshold of $0.2 \mathrm{~m} \mathrm{~s}^{-1}$ as described above. The effect of random error on the uncertainty of annual NEP was calculated by assigning a random error of $20 \%$ to each half-hourly measurement (Wesely and Hart, 1985; Morgenstern et al., 2004). A Monte Carlo simulation was used to obtain the uncertainty in gap-filling where gaps up to $40 \%$ of the year were generated using a uniformly distributed random number generator with continuous gaps of up to 10 days (Krishnan et al., 2006). The missing data were then filled using the soil temperature and light response functions as described above (Eqs. 2 and 3 ) and the new annual sums of NEP, GEP and $R_{\mathrm{e}}$ were calculated. The procedure was repeated 500 times in order to determine the $95 \%$ confidence interval. All data analysis and statistical calculations were carried out with Matlab (Version 7.5.0, The MathWorks, Natick, MA, USA).

To assess the quality of the EC measurements, an energy balance closure analysis was conducted but a correction was not applied to the flux data. The sum of the turbulent fluxes of sensible $(H)$ and latent heat $(\lambda E)$, where $\lambda$ is the latent heat of vaporization, was plotted against the available energy flux, which was computed as net radiation minus soil heat flux minus the rate of change in energy storage in the air column and biomass per unit ground area (Brown et al., 2013). The slope of the regression line remained constant at 0.80 during the two years of measurements.

\section{Results}

\subsection{Climate data}

The climate at the site is characterized by cold winters and short warm summers with moderate annual precipitation $(P)$ typical for the Sub-Boreal Spruce zone. Historical mean annual air temperature $\left(T_{\mathrm{a}}\right)$ measured at the Prince George Airport is $4{ }^{\circ} \mathrm{C}$ for $1971-2000$ (Environment Canada, 2012). Measurements at MPB-09 showed that 2010 was a warmer and drier year with a mean annual $T_{\mathrm{a}}$ of $4.9^{\circ} \mathrm{C}$ compared to $3.0^{\circ} \mathrm{C}$ in 2011 (Fig. 2; Table 2). Growing season rainfall in 2010 was $120 \mathrm{~mm}$ less than in 2011. During the dry summer of 2010, volumetric soil water content $(\theta)$ at the $3 \mathrm{~cm}$ depth decreased to its lowest value of $0.26 \mathrm{~m}^{3} \mathrm{~m}^{-3}$ on $21 \mathrm{Au}-$ gust, with only $16 \mathrm{~mm}$ of rainfall during the previous 55 days (Fig. 3). The corresponding soil water matric potential of $-200 \mathrm{kPa}$ suggests that soil water was available to plants at $\theta>0.26 \mathrm{~m}^{3} \mathrm{~m}^{-3}$. In contrast, $156 \mathrm{~mm}$ of rain fell during the same period in the following year during which $\theta$ remained at an average value of $0.55 \mathrm{~m}^{3} \mathrm{~m}^{-3}$. An extended dry period in 2010 was also observed at two lodgepole pine stands nearby (Brown et al., 2012). Annual $P$ at MPB-09 increased from $506 \mathrm{~mm}$ in 2010 to $864 \mathrm{~mm}$ in 2011. The coldest wintertime temperatures observed at the site during the two years of study were $-30^{\circ} \mathrm{C}$ on 23 November 2010 and $-33^{\circ} \mathrm{C}$
Table 2. Mean annual and growing season climate conditions at MPB-09.

\begin{tabular}{lll}
\hline & 2010 & 2011 \\
\hline$T_{\mathrm{a}}(26 \mathrm{~m})\left({ }^{\circ} \mathrm{C}\right)$ & $4.9(12.7)^{\mathrm{a}}$ & $3.0(11.6)$ \\
$T_{\mathrm{S}}(3 \mathrm{~cm})\left({ }^{\circ} \mathrm{C}\right)$ & $6.1(12.0)$ & $5.3(10.9)$ \\
$P(\mathrm{~mm})$ & $506(225)$ & $864(343)$ \\
$\theta\left(\mathrm{m}^{3} \mathrm{~m}^{-3}\right)(3 \mathrm{~cm} \mathrm{depth})$ & $0.49(0.44)$ & $0.55(0.55)$ \\
$Q\left(\mu \mathrm{mol} \mathrm{m}^{-2} \mathrm{~s}^{-1}\right)^{\mathrm{b}}$ & $245(406)$ & $224(345)$ \\
Growing season length $^{\mathrm{c}}$ (days) & 158 & 146 \\
\hline
\end{tabular}

a Growing season values are in parentheses.

b $24 \mathrm{~h}$ average.

${ }^{\mathrm{c}}$ Growing season length defined as days when daily mean $T_{\mathrm{a}}>0{ }^{\circ} \mathrm{C}$ and $T_{\mathrm{S}}>1{ }^{\circ} \mathrm{C}$.

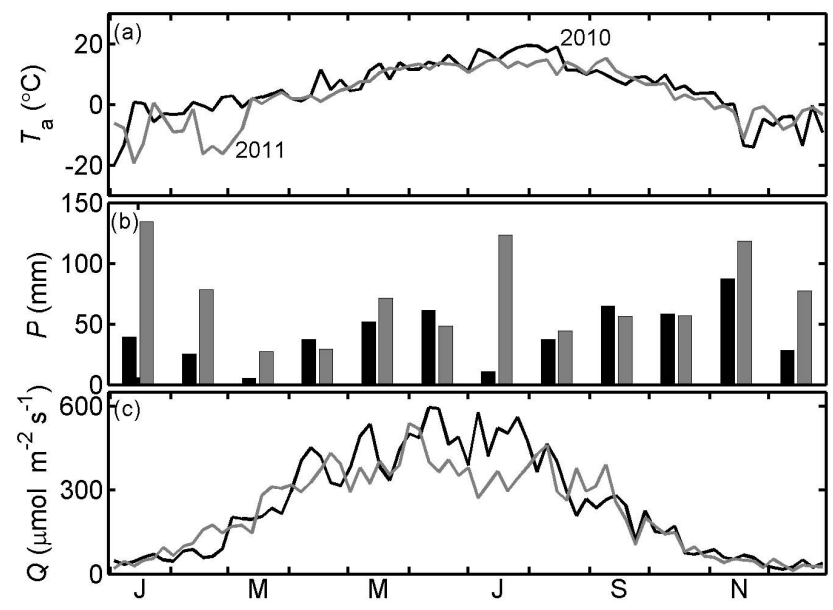

Fig. 2. Climate data at MPB-09 for 2010 and 2011 with (a) 5-day averaged air temperature $\left(T_{\mathrm{a}}\right)$, (b) monthly total precipitation $(P)$ and (c) 5-day averaged downwelling PAR $(Q)$.

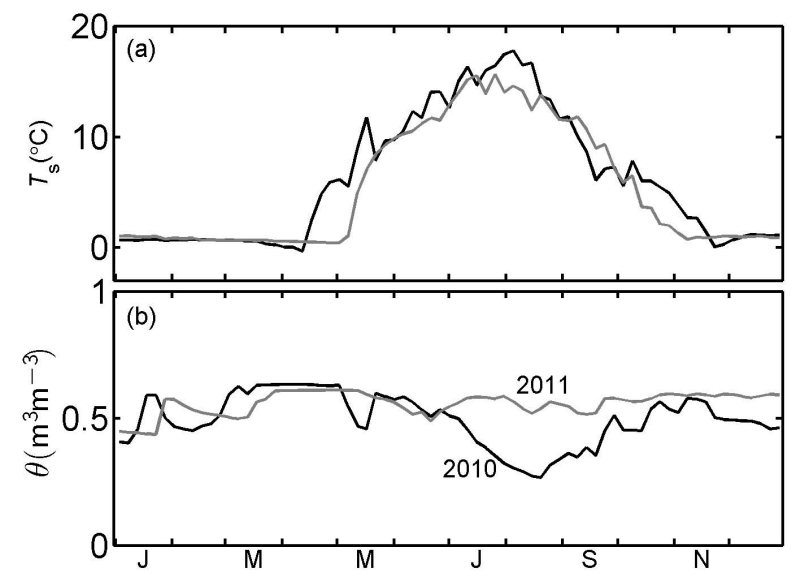

Fig. 3. Interannual variability in (a) 5-day averaged soil temperature $\left(T_{\mathrm{S}}\right)$ and (b) volumetric soil water content $(\theta)$ at the $3 \mathrm{~cm}$ depth at MPB-09 for 2010 and 2011. 
on 19 February 2011. During both years, snowfall began in mid-November and a $1 \mathrm{~m}$-deep snow layer persisted for 45 months during the winter. During this time, a minimum $T_{\mathrm{s}}$ of $-0.5^{\circ} \mathrm{C}$ was observed near the soil surface at the $3 \mathrm{~cm}$ depth. Snowmelt was complete on 2 April 2010 and 27 April 2011 , and was followed by an increase in $T_{\mathrm{S}}$ in the upper 20 $\mathrm{cm}$ of the soil profile. The growing season length (daily mean $T_{\mathrm{a}}>0{ }^{\circ} \mathrm{C}$ and daily mean $T_{\mathrm{s}}$ at the $3 \mathrm{~cm}$ depth $>1{ }^{\circ} \mathrm{C}$ ) lasted almost two weeks longer in 2010 than in 2011.

\subsection{Seasonal and diurnal variation in NEP}

Monthly $\mathrm{C}$ exchange varied between the two years and their seasons (Fig. 4). NEP was greater during the spring of 2010 than in 2011. In 2010, the monthly total NEP was $8.6 \mathrm{~g} \mathrm{C} \mathrm{m}^{-2}$ in April and $3.7 \mathrm{~g} \mathrm{C} \mathrm{m}^{-2}$ in May, whereas in 2011 it was $4.8 \mathrm{~g} \mathrm{C} \mathrm{m}^{-2}$ and $4.0 \mathrm{~g} \mathrm{C} \mathrm{m}^{-2}$ in the two months respectively. In 2010, the earlier onset of spring with higher $T_{\mathrm{a}}$ and $T_{\mathrm{S}}$ compared to 2011 , led to a greater $\mathrm{C}$ uptake during the daytime, which more than compensated for the high $\mathrm{C}$ losses during the nighttime in April and May. In both years, the highest NEP was in June, with monthly total values of 25.1 and $42.9 \mathrm{~g} \mathrm{C} \mathrm{m}^{-2}$ in 2010 and 2011, respectively. Monthly total NEP in June 2011 was almost twice the value of June 2010, due to much higher daytime values in 2011, while nighttime values remained the same. The greater $\mathrm{C}$ uptake during the daytime in 2011 was due to a higher GEP as a result of increasing vegetation growth, perhaps in response to more light penetration through the canopy and reduced competition for nutrients and water following the lodgepole pine removal. Nighttime $\mathrm{C}$ loss reached its highest values in July of both years with minimum NEP values of $-5.7 \mu \mathrm{mol} \mathrm{m}^{-2} \mathrm{~s}^{-1}$ in 2010 and $-8.2 \mu \mathrm{mol} \mathrm{m}^{-2} \mathrm{~s}^{-1}$ in 2011 (Fig. 4d). During the second half of the growing season monthly NEP declined in both years and became negative in August 2010 but remained positive in August 2011 (Fig. 4e). This shows that while $R_{\mathrm{e}}$ dominated in August 2010, GEP dominated in August 2011. By September, $\mathrm{CO}_{2}$ respired during the nighttime exceeded photosynthetic uptake during the daytime leading to a negative monthly NEP in both years.

\subsection{Annual NEP, GEP and $R_{\mathrm{e}}$}

The annual courses of the 5-day averages of NEP, GEP and $R_{\mathrm{e}}$, along with $E$ are shown in Fig. 5. In both 2010 and 2011, NEP was generally positive during the growing season with a greater $\mathrm{CO}_{2}$ uptake in 2011. NEP reached its lowest value of $-1.9 \mathrm{~g} \mathrm{C} \mathrm{m}^{-2} \mathrm{day}^{-1}$ in October 2010 and September 2011. In July, GEP reached its highest value of $6.7 \mathrm{~g} \mathrm{C} \mathrm{m}^{-2}$ day $^{-1}$ in 2010 and $9.4 \mathrm{~g} \mathrm{C} \mathrm{m}^{-2}$ day $^{-1}$ in 2011. The highest value of $R_{\mathrm{e}}$ was also observed in July, increasing from $6.0 \mathrm{~g} \mathrm{C} \mathrm{m}^{-2} \mathrm{day}^{-1}$ in 2010 to $8.4 \mathrm{~g} \mathrm{C} \mathrm{m}^{-2}$ day $^{-1}$ in 2011. During the wintertime when $R_{\mathrm{e}}$ dominated the forest $\mathrm{C}$ balance, the average values of NEP in 2010 and

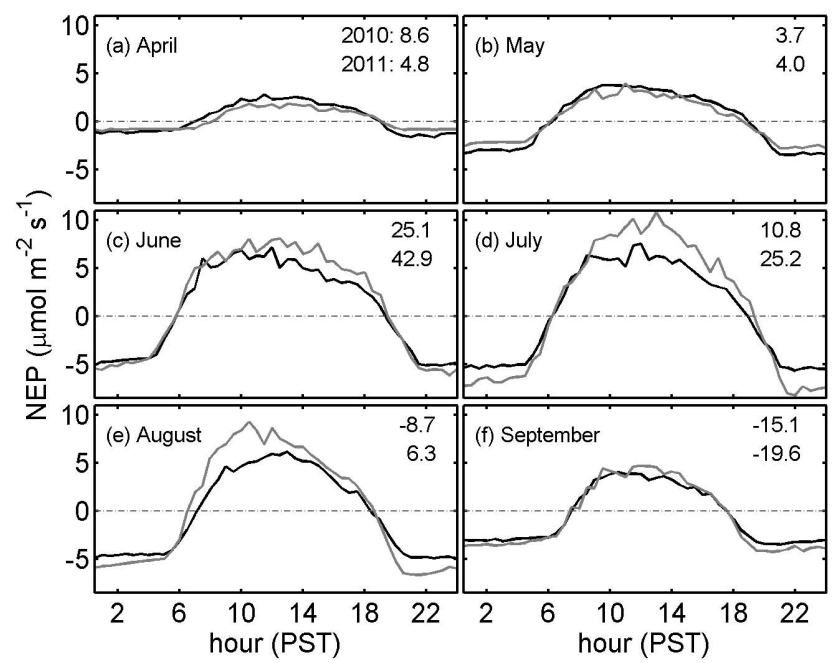

Fig. 4. Ensemble-averaged diurnal net ecosystem production (NEP) during the growing season of 2010 (black lines) and 2011 (grey lines) showing (a) April (b) May (c) June (d) July (e) August and (f) September. Monthly NEP values for the two years shown in the panels are in $\mathrm{g} \mathrm{C} \mathrm{m}^{-2}$ month $^{-1}$.

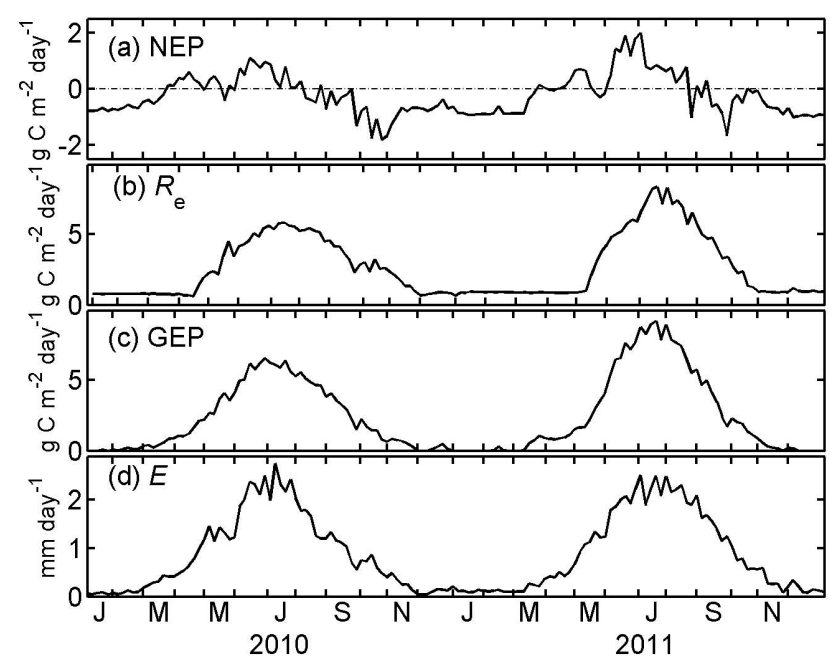

Fig. 5. 5-day averaged (a) net ecosystem production (NEP), (b) ecosystem respiration $\left(R_{\mathrm{e}}\right)$ (c) gross ecosystem photosynthesis (GEP) and (d) evapotranspiration (E) in 2010 and 2011.

2011 were $-0.57 \mathrm{~g} \mathrm{C} \mathrm{m}^{-2} \mathrm{day}^{-1}$ and $-0.76 \mathrm{~g} \mathrm{C} \mathrm{m}^{-2} \mathrm{day}^{-1}$, respectively.

Annual NEP increased from $-108 \mathrm{~g} \mathrm{C} \mathrm{m}^{-2} \mathrm{yr}^{-1}$ in 2010 to $-57 \mathrm{~g} \mathrm{C} \mathrm{m}^{-2} \mathrm{yr}^{-1}$ in 2011 (Fig. 6; Table 3). The stand remained an annual $\mathrm{C}$ source in both years, but the $\mathrm{C}$ loss was lower in the second year. GEP increased from $812 \mathrm{~g} \mathrm{C} \mathrm{m}^{-2} \mathrm{yr}^{-1}$ in 2010 to $954 \mathrm{~g} \mathrm{C} \mathrm{m}^{-2} \mathrm{yr}^{-1}$ in 2011. This increase was greater than that of $R_{\mathrm{e}}$, which was from $920 \mathrm{~g} \mathrm{C} \mathrm{m}^{-2} \mathrm{yr}^{-1}$ in 2010 to $1011 \mathrm{~g} \mathrm{C} \mathrm{m}^{-2} \mathrm{yr}^{-1}$ in 2011 . The proportionally greater increase in GEP in relation to that of $R_{\mathrm{e}}$, in the second year after harvesting explains the 
Table 3. Annual totals of net ecosystem production (NEP), gross ecosystem photosynthesis (GEP), ecosystem respiration $\left(R_{\mathrm{e}}\right)$ in and evapotranspiration $(E)$ at MPB-09*. Values in parentheses show the lower and upper $95 \%$ confidence intervals for the annual totals derived from the Monte Carlo simulation (see Sect. 2.3.2 for details).

\begin{tabular}{lllll}
\hline & $\begin{array}{l}\text { NEP } \\
\left(\mathrm{gC} \mathrm{m}^{-2} \mathrm{yr}^{-1}\right)\end{array}$ & $\begin{array}{l}\text { GEP } \\
\left(\mathrm{g} \mathrm{C} \mathrm{m}^{-2} \mathrm{yr}^{-1}\right)\end{array}$ & $\begin{array}{l}R_{\mathrm{e}} \\
\left(\mathrm{g} \mathrm{C} \mathrm{m}^{-2} \mathrm{yr}^{-1}\right)\end{array}$ & $\begin{array}{l}E \\
(\mathrm{~mm})\end{array}$ \\
\hline 2010 & $-108(-120,-98)$ & $812(798,823)$ & $920(908,929)$ & 316 \\
2011 & $-57(-72,-45)$ & $954(932,971)$ & $1011(987,1040)$ & 332 \\
\hline
\end{tabular}

* Recent analysis indicates that in 2012, annual totals of NEP, GEP and $R_{\mathrm{e}}$ at MPB-09 were $-52,922$ and $974 \mathrm{~g} \mathrm{C} \mathrm{m}^{-2}$, respectively.

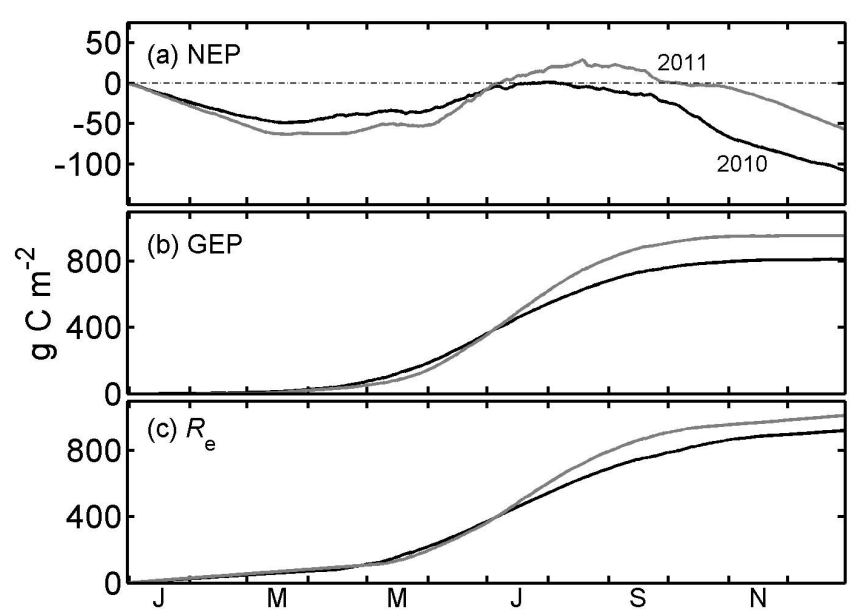

Fig. 6. Cumulative annual (a) net ecosystem production (NEP), (b) gross ecosystem photosynthesis (GEP) and (c) ecosystem respiration $\left(R_{\mathrm{e}}\right)$ in 2010 and 2011.

significant increase of NEP despite the shorter growing season length in 2011. The $95 \%$ confidence intervals on the annual totals of NEP, GEP and $R_{\mathrm{e}}$ indicate that the annual values were significantly different in the two years and that the stand was clearly a C source in 2010 and 2011 (Table 3). Furthermore, the $20 \%$ random error associated with each halfhour measurement of NEP resulted in an uncertainty of less than $3 \mathrm{~g} \mathrm{C} \mathrm{m}^{-2} \mathrm{yr}^{-1}$ in both years.

\subsection{Environmental controls on $R_{\mathrm{e}}$ and GEP}

The relationship between nighttime $R_{\mathrm{e}}$ and $T_{\mathrm{S}}$ at the $3 \mathrm{~cm}$ depth was described using the logistic model (Eq. 2; Fig. 7). At lower $T_{\mathrm{s}}, R_{\mathrm{e}}$ showed a similar response in both years. For $T_{\mathrm{S}}>10^{\circ} \mathrm{C}$, the increase of $R_{\mathrm{e}}$ was greater in $2011 . T_{\mathrm{S}}$ explained $58 \%$ of the variance in $R_{\mathrm{e}}$ in 2010 and $48 \%$ in 2011. The relationship between temperature-normalized $R_{\mathrm{e}}$ and $\theta$ at the $3 \mathrm{~cm}$ depth was found to be very weak $\left(r^{2}=0.0036\right)$ indicating that the difference in response at higher temperatures could not be explained by differences in soil moisture between the two years. For $T_{\mathrm{S}}>10^{\circ} \mathrm{C}$, higher values of $R_{\mathrm{e}}$ in 2011 were likely due to higher autotrophic respiration $\left(R_{\mathrm{a}}\right)$ associated with higher GEP in that year.

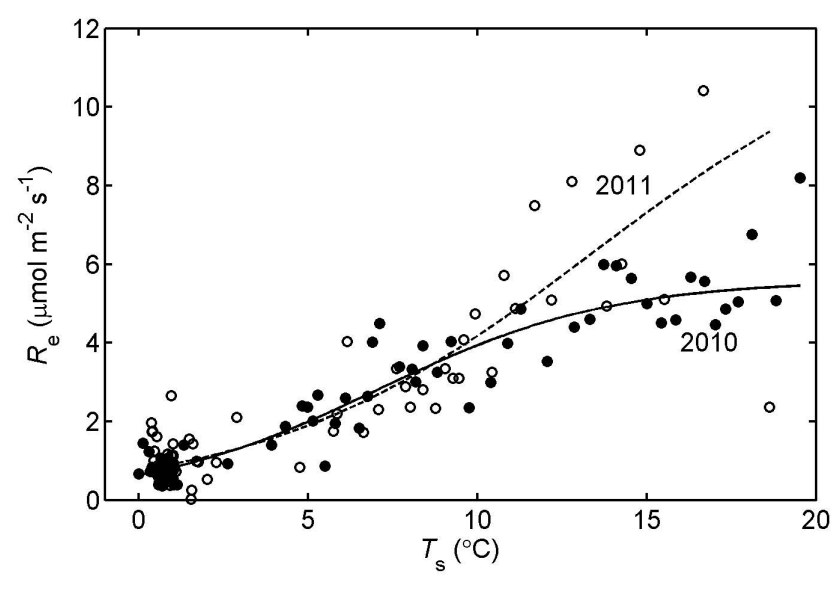

Fig. 7. Relationship between nighttime ecosystem respiration $\left(R_{\mathrm{e}}\right)$ with friction velocity threshold $\left(u_{* \text { th }}\right)$ applied $\left(u_{* \text { th }}=0.2 \mathrm{~m} \mathrm{~s}^{-1}\right)$ and $3 \mathrm{~cm}$ soil temperature $\left(T_{\mathrm{S}}\right)$ in 2010 and 2011 . Each data point is an average of 10 half-hour values. The equation parameters are given in Table 4.

The relationship between GEP and $Q$ was modeled using the rectangular hyperbolic light response function, i.e. the Michaelis-Menten relationship (Eq. 3). The photosynthetic capacity $\left(A_{\max }\right)$ increased by $26 \%$ from $12.1 \mu \mathrm{mol} \mathrm{m}^{-2} \mathrm{~s}^{-1}$ in 2010 to $15.2 \mu \mathrm{mol} \mathrm{m}^{-2} \mathrm{~s}^{-1}$ in 2011 (Fig. 8; Table 4). Moreover, quantum yield $(\alpha)$ increased from $0.044 \mathrm{~mol} \mathrm{C} \mathrm{mol}^{-1}$ photons in 2010 to $0.066 \mathrm{~mol} \mathrm{C} \mathrm{mol}^{-1}$ photons in 2011.

\subsection{Evapotranspiration}

The seasonal course of $E$ at MPB-09 followed more or less that of GEP (Fig. 5d). The maximum 5-day average $E$ occurred at the beginning of July and was $2.8 \mathrm{~mm} \mathrm{day}^{-1}$ in 2010 and $2.6 \mathrm{~mm} \mathrm{day}^{-1}$ in $2011 . E$ was generally higher during the first part of the 2010 than in the following year, but declined in late summer (July to September) due to reduced rainfall. Annual $E$ at MPB-09 was $316 \mathrm{~mm}$ in 2010 and $332 \mathrm{~mm}$ in 2011 (Table 3). Brown et al. (2012) obtained a similar annual value $(284 \mathrm{~mm})$ for 2010 in an unharvested MPB-attacked stand with significant secondary structure located $30 \mathrm{~km}$ north of MPB-09. A highly significant 
Table 4. Parameters for the relationships of nighttime respiration $\left(R_{\mathrm{e}}\right)$ to soil temperature at the $3 \mathrm{~cm}$ depth $\left(T_{\mathrm{S}}\right)$ using the logistic equation, and the relationships of gross ecosystem photosynthesis (GEP) to downwelling PAR $(Q)$ using the Michaelis-Menten function.

\begin{tabular}{|c|c|c|c|c|c|c|c|}
\hline \multirow[t]{2}{*}{ Year } & \multicolumn{4}{|c|}{ Nighttime $R_{\mathrm{e}}$ and $T_{\mathrm{S}}$} & \multicolumn{3}{|c|}{ GEP and $Q$} \\
\hline & 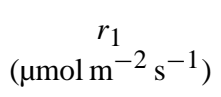 & $\left(\begin{array}{c}r_{2} \\
\left({ }^{\circ} \mathrm{C}^{-1}\right)\end{array}\right.$ & $\begin{array}{c}r_{3} \\
\left({ }^{\circ} \mathrm{C}\right)\end{array}$ & $r^{2}$ & 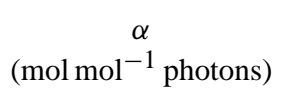 & $\begin{array}{c}A_{\max } \\
\left(\mu \mathrm{mol} \mathrm{m} \mathrm{m}^{-2} \mathrm{~s}^{-1}\right)\end{array}$ & $r^{2}$ \\
\hline 2010 & 5.55 & 0.30 & 6.92 & 0.58 & 0.044 & 12.1 & 0.26 \\
\hline 2011 & 12.73 & 0.21 & 13.50 & 0.48 & 0.066 & 15.2 & 0.26 \\
\hline
\end{tabular}

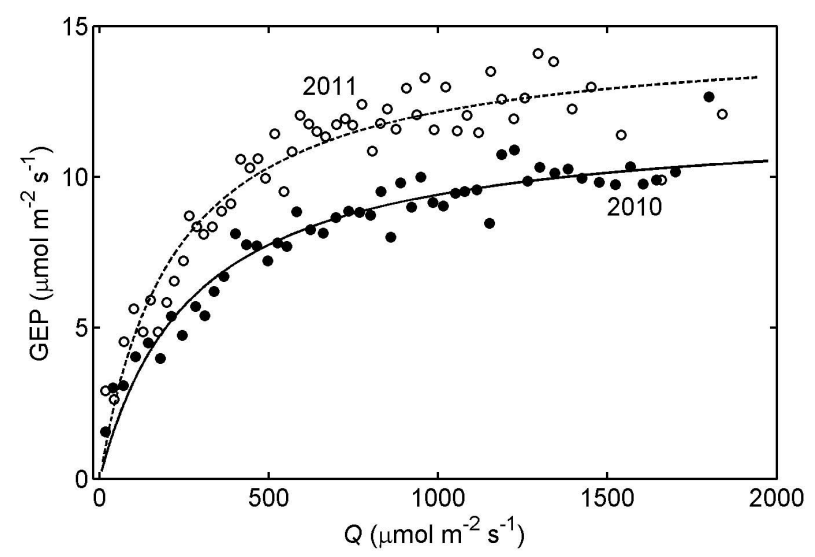

Fig. 8. Light-response curve showing gross ecosystem photosynthesis (GEP) plotted against downwelling PAR $(Q)$ for 2010 and 2011. Each data point is an average of 50 half-hour values. The equation parameters are given in Table 4.

linear correlation $\left(r^{2}=0.98, p<0.001\right)$ was found between monthly mean values of GEP and $E$ for both years with a mean monthly water use efficiency (WUE $=\mathrm{GEP} / E$ ) of $3.24 \mathrm{~g} \mathrm{C} \mathrm{kg}^{-1} \mathrm{H}_{2} \mathrm{O}$ (Fig. 9). However, growing season average WUE in 2010 of $2.77 \mathrm{~g} \mathrm{C} \mathrm{kg}^{-1} \mathrm{H}_{2} \mathrm{O}$ was lower than the value of $3.15 \mathrm{~g} \mathrm{C} \mathrm{kg}^{-1} \mathrm{H}_{2} \mathrm{O}$ in 2011. The lower value in 2010 may be due to the higher contribution of soil evaporation in 2010 caused by sparse groundcover following the harvesting disturbance.

\subsection{Comparison of NEP following partial and clear-cut harvesting}

During the period between June and September 2010, the clear-cut (MPB-09C) was a C source with monthly total $\mathrm{NEP}$ values ranging from $-15 \mathrm{~g} \mathrm{C} \mathrm{m}^{-2} \mathrm{month}^{-1}$ in June to $-50 \mathrm{~g} \mathrm{C} \mathrm{m}^{-2}$ month $^{-1}$ in September (Fig. 10). In comparison, the partially harvested stand (MPB-09) was a C sink in June and July and a weak source in August and September of 2010. For all 4 months, MPB-09C was a large C source of $103 \mathrm{~g} \mathrm{C} \mathrm{m}^{-2}$, while MPB-09 was a weak C sink of $9 \mathrm{~g} \mathrm{C} \mathrm{m}^{-2}$ over the same time period of 2010 and of $47 \mathrm{~g} \mathrm{C} \mathrm{m}^{-2}$ in 2011 (Table 5). Furthermore, GEP and $R_{\mathrm{e}}$ totals were $294 \mathrm{~g} \mathrm{C} \mathrm{m}^{-2}$ and $397 \mathrm{~g} \mathrm{C} \mathrm{m}^{-2}$ for MPB-09C and $530 \mathrm{~g} \mathrm{C} \mathrm{m}^{-2}$ and $521 \mathrm{~g} \mathrm{C} \mathrm{m}^{-2}$ for MPB-09, respectively. Av-

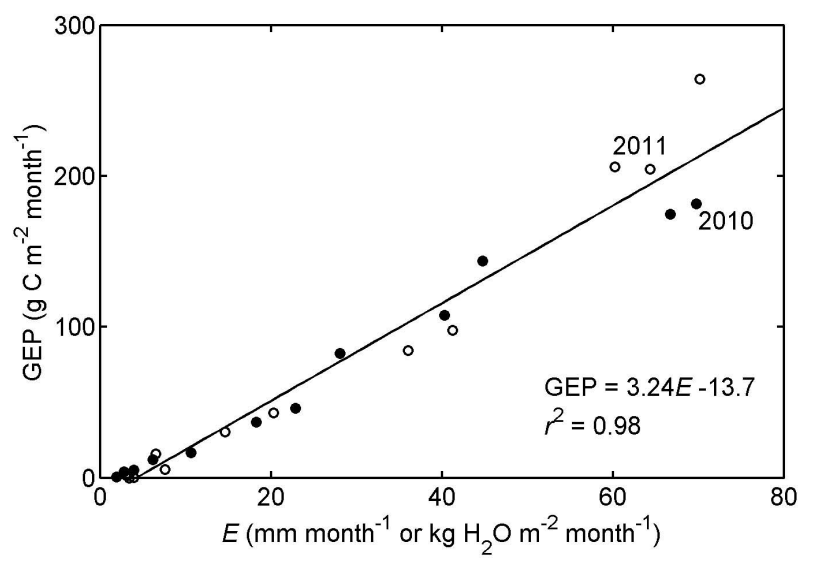

Fig. 9. Relationship between monthly mean gross ecosystem photosynthesis (GEP) and evapotranspiration $(E)$ at MPB-09 in 2010 and 2011. The line and equation is the linear regression relationship for all points.

erage daily (24h) NEP at MPB-09C was $-1.0 \mathrm{~g} \mathrm{C} \mathrm{m}^{-2}$. In comparison, measurements made in a nearby 2 -year-old clear-cut and a 10-year-old clear-cut in July and August of 2007 showed the average daily NEP to be -0.87 and $-0.37 \mathrm{~g} \mathrm{C} \mathrm{m}^{-2}$, respectively (Brown et al., 2010).

\section{Discussion}

\subsection{NEP of the partially harvested stand}

In the first two years after partial harvesting the MPBattacked stand, MPB-09 was a C sink during the growing season, but the high $R_{\mathrm{e}}$ during winter months caused it to be an annual $\mathrm{C}$ source in both years. The annual NEP increased from $-108 \mathrm{~g} \mathrm{C} \mathrm{m}^{-2}$ in 2010 to $-57 \mathrm{~g} \mathrm{C} \mathrm{m}^{-2}$ in 2011 . Both GEP and $R_{\mathrm{e}}$ increased in the second year after harvesting but the increase of GEP was greater, resulting in a higher $\mathrm{C}$ uptake by the stand compared to the previous year. The cooler and wetter conditions in 2011 may have provided favorable conditions for plant growth, enhancing recovery of the residual stand. Although the growing season lasted two weeks longer in 2010 , the greater $\mathrm{C}$ uptake during the midsummer of 2011 played a more important role in determining the annual NEP at MPB-09. High C losses observed in 


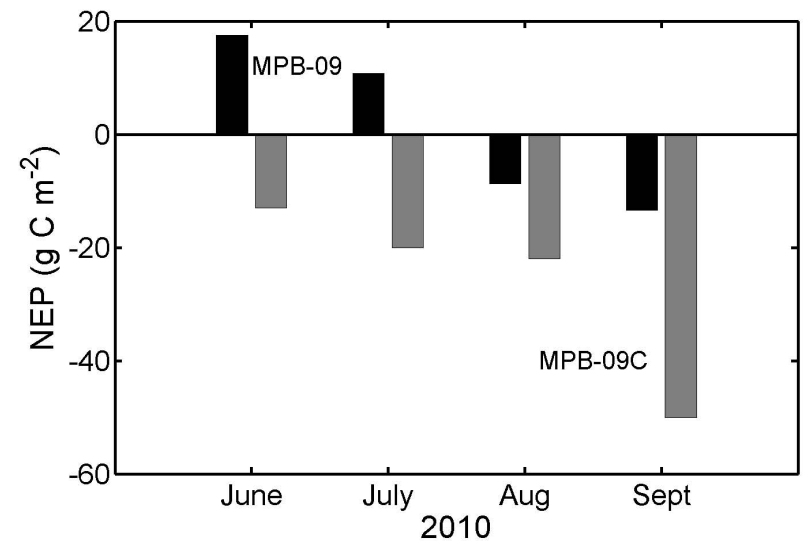

Fig. 10. Monthly total net ecosystem production (NEP) from 10 June to 22 September of 2010 for MPB-09 and MPB-09C.

August and September coincided with warm soil conditions that would result in an increase in $R_{\mathrm{h}}$ from the decomposing coarse woody debris (Mkhabela et al., 2009; Barr et al., 2007).

The greatest C uptake at MPB-09 was in June when leaf emergence of the understory broadleaf vegetation occurred. This was also observed in an unharvested beetle-killed stand located approximately $30 \mathrm{~km}$ north of the study site (Brown et al., 2010). There, the majority (65-68\%) of GEP was found to have come from the understory non-tree species, indicating the importance of broadleaf residual vegetation in the $\mathrm{C}$ uptake of these disturbed sub-boreal forests (Bowler et al., 2012). The compensatory effects of the surviving vegetation following thinning is known to lead to vegetation shifts through less competition for resources such as light, nutrients and water (Campbell et al., 2009; Saunders et al., 2012; Vesala et al., 2005). By removing trees from a stand, the forest canopy opens up, allowing more light to penetrate through the canopy and increase the photosynthetic capacity of the underlying vegetation (Saunders et al., 2012). The significant contribution of understory $\mathrm{CO}_{2}$ uptake was also found in a ponderosa pine (Pinus ponderosa) forest, showing a shift in species following thinning (Misson et al., 2005). The abundance of understory broadleaf vegetation at MPB09 highlights its importance in determining the NEP of the partially harvested stand, such that the increase of shrub LAI compensates for the loss of tree LAI following the disturbance.

While no data are available prior to harvesting at this site, studies have consistently shown a reduction of GEP after forest thinning and clear-cutting due to the removal of aboveground biomass (Misson et al., 2005; Dore et al., 2010; Campbell et al., 2009; Giasson et al., 2006). Misson et al. (2005) found that forest thinning in a young ponderosa pine forest in the Sierra Nevada of California had a greater impact on GEP than $R_{\mathrm{e}}$. Consequently the forest became a weak $\mathrm{C}$ source of $13 \mathrm{~g} \mathrm{C} \mathrm{m}^{-2}$ after thinning but shifted back
Table 5. Net ecosystem production (NEP), gross ecosystem photosynthesis (GEP) and ecosystem respiration $\left(R_{\mathrm{e}}\right)$ totals for the clearcut (MPB-09C) and the partially harvested stand (MPB-09) during the summer (10 June-22 September) of 2010 and 2011*. Values in parentheses show the lower and upper $95 \%$ confidence intervals for the growing season totals derived from Monte Carlo simulation.

\begin{tabular}{llll}
\hline & $\begin{array}{l}\text { NEP } \\
\left(\mathrm{g} \mathrm{C} \mathrm{m}^{-2}\right)\end{array}$ & $\begin{array}{l}\text { GEP } \\
\left(\mathrm{g} \mathrm{C} \mathrm{m}^{-2}\right)\end{array}$ & $\begin{array}{l}R_{\mathrm{e}} \\
\left(\mathrm{g} \mathrm{C} \mathrm{m}^{-2}\right)\end{array}$ \\
\hline MPB-09C 2010 & -103 & 294 & 397 \\
& $(-131,-78)$ & $(254,341)$ & $(388,521)$ \\
MPB-09 2010 & 9 & 530 & 521 \\
MPB-09 2011 & 47 & 712 & 665 \\
\hline
\end{tabular}

* Recent analysis indicates that 2012 growing season NEP, GEP and $R_{\mathrm{e}}$ values for MPB-09 were 74, 700 and $626 \mathrm{~g} \mathrm{C} \mathrm{m}^{-2}$, respectively.

to a C sink after one year. At MPB-09, both GEP and $R_{\mathrm{e}}$ were higher in 2011 even though air temperature was above the historical average and incident PAR was greater in 2010. As shown by the light response curve, the photosynthetic capacity of the stand increased in the second year after harvesting. The observed increase of NEP could be attributed to stand regeneration as an increase in the understory vegetation was observed from 2010 to 2011.

There was virtually no relationship of $R_{\mathrm{e}}$ to $\theta$ at the $3 \mathrm{~cm}$ depth. The soil water matric potential during the dry period in the summer of 2010 was well above the permanent wilting point indicating that the trees weren't water stressed during low $\theta$ conditions in 2010. Dilustro et al. (2005) found that $R_{\mathrm{S}}$ and $\theta$ correlated significantly at sandy sites but not at clayey sites in managed mixed pine forests in southeastern Georgia, as the fine-textured soils buffer soil water effects on $R_{\mathrm{S}}$ due to a slow release of water. The increase in $R_{\mathrm{e}}$ observed at this site in the second year after the disturbance may have been due to an increase of $R_{\mathrm{a}}$, as a result of increased GEP as the forest recovers (Jassal et al., 2007).

Evapotranspiration followed a similar pattern as GEP, increasing in the second year of harvesting. A higher photosynthetic uptake by the increasing biomass was likely associated with the increase in stomatal conductance and transpiration of the residual stand. WUE increased in 2011, possibly due to lower soil evaporation resulting from a greater groundcover in the second year after partial harvesting. It has been previously shown that recently disturbed forests increase their WUE as the stand recovers and closes its canopy, leading to more transpiration and photosynthesis from the leaves compared to evaporation from the ground (Mkhabela et al., 2009).

\subsection{Comparison of NEP of the partially harvested stand and clear-cut}

The clear-cut, MPB-09C, was a large C source, whereas MPB-09 was a weak C sink from June to September of 
2010. Since they both had the same site characteristics, such as vegetation, soil type, time of harvest and climate conditions, the results indicate that harvesting intensity has a major impact on the net $\mathrm{CO}_{2}$ emissions from the forest. By retaining the healthy secondary structure, the GEP of the partially harvested stand was greater, resulting in $\mathrm{C}$ uptake during the growing season of 2010. Total $\mathrm{C}$ loss during the measurement period in the clear-cut was $103 \mathrm{~g} \mathrm{C} \mathrm{m}^{-2}$ with an average daily loss of $1.0 \mathrm{~g} \mathrm{C} \mathrm{m}^{-2}$. Since photosynthesis would be largely absent for the remainder of the year, MPB09C was likely a large annual C source. Sub-boreal clearcuts in the area that were replanted with lodgepole pine seedlings have been shown to still be summertime $\mathrm{C}$ sources of $0.37 \mathrm{~g} \mathrm{C} \mathrm{m}^{-2}$ day $^{-1}$ after $10 \mathrm{yr}$ (Brown et al., 2010). Pypker and Fredeen (2002) found a 6-year-old clear-cut planted with hybrid white spruce seedlings to be an average daily $\mathrm{C}$ source of $0.9 \mathrm{~g} \mathrm{C} \mathrm{m}^{-2}$ over the growing season. In this study, both GEP and $R_{\mathrm{e}}$ were greater at MPB-09 than at MPB-09C during the summertime.

There is limited research into the effects of management responses to insect outbreaks on the $\mathrm{C}$ balance of forests. This study shows that partial harvesting following an MPB attack reduces $\mathrm{C}$ losses as compared to clear-cut harvesting. Previous findings from a study at two beetle-killed lodgepole pine stands nearby that were left to recover naturally, found the stands to recover faster than previously hypothesized and becoming $\mathrm{C}$ neutral annually within 3 to $5 \mathrm{yr}$ after attack (Brown et al., 2010; Brown et al., 2012). In 2010, MPB-09 was a greater $C$ source than the unharvested beetlekilled stands, which at that point had reached the grey-attack stage, when the pine trees were dead and most of the needles had fallen. Furthermore, one year after partial harvesting, MPB-09 was losing more $\mathrm{CO}_{2}$ annually than one year after the insect attack in one of the unharvested stands described in Brown et al. (2010). This suggests that for these sites the harvesting disturbance likely had a greater impact on NEP than the MPB attack itself.

Consequently, the choice of management strategy in response to MPB outbreak can have a major impact on NEP. The clear-cut, MPB-09C, was a much larger C source, indicating that partial harvesting is more favorable in reducing the $\mathrm{CO}_{2}$ emissions of the stand. Since the healthy trees are retained, more aboveground biomass results in a higher photosynthetic capacity of the stand and a higher annual NEP compared to clear-cut harvesting. Windthrow can potentially affect the $\mathrm{C}$ balance of the residual stand after harvesting due to greater wind loads on retained trees. The risk of windthrow was initially thought to be significant in the case of MPB-09, however Nishio (2011) showed that one year after harvesting, windthrow at this site was only $9 \%$, indicating the trees were developing windfirm characteristics. This may in part be explained by the location of the stand downwind of an open area, which tends to have high wind speeds and may have resulted in the trees in the stand previously becoming windfirm (Nishio, 2011). Recent analysis of measurements in 2012 indicate that the growing season C sink at MPB09 increased to $74 \mathrm{~g} \mathrm{C} \mathrm{m}^{-2}$ although annual NEP remained virtually the same as in 2011 (Tables 3 and 5). Our results suggest that if the residual forest continues its current rate of recovery, the stand would likely return to a $\mathrm{C}$ sink more quickly than clear-cuts in the area, which as indicated above, can remain a $\mathrm{C}$ source for at least $10 \mathrm{yr}$. The understory LAI would likely continue to increase until the tree canopy closes and less solar radiation reaches the forest floor, thus increasing the contribution of the tree canopy to $\mathrm{CO}_{2}$ uptake relative to the understory.

\section{Conclusions}

This study examined the effects of partial and clear-cut harvesting on the $\mathrm{C}$ balance of a sub-boreal forest that was previously attacked by the MPB. Annual NEP at MPB-09 increased from the first to the second year after harvesting, with the stand remaining an annual $\mathrm{C}$ source in both years. The increase of GEP observed in 2011 was greater than the increase in $R_{\mathrm{e}}$, indicating that the photosynthetic capacity of the forest played a major role in increasing annual NEP. The remaining healthy spruce and subalpine fir trees and understory vegetation in the partially harvested stand contributed to C uptake, which will likely enable the forest to return to $\mathrm{C}$ neutrality at a faster rate than clear-cuts. In the first two years after partial harvesting, MPB-09 was a growing-season C sink, which increased from 2010 to 2011. In contrast, the clear-cut, MPB09C, was a large C source from June until September and likely an even larger $\mathrm{C}$ source annually. These results suggest that when considering forest management practices in response to the MPB outbreak, partial harvesting can result in greater NEP compared to clear-cut harvesting by retaining the healthy residual vegetation.

Acknowledgements. This research was supported by an NSERC (Natural Sciences and Engineering Research Council) Strategic Grant and an NSERC Discovery Grant to T.A. Black, as well as grants from the Canadian Foundation for Climate and Atmospheric Science (CFCAS) and the BC Ministry of Forests, Lands and Natural Resource Operations. We appreciate the technical support by Dominic Lessard, Rick Ketler, Iain Hawthorne, Andrew Hum and Trevor Baker at the UBC Biometeorology and Soil Physics Group and by Vanessa Foord at the BC Ministry of Forests, Lands and Natural Resource Operations. Many thanks also to Nicholas Conder and Dave Dunn, Pacific Forestry Centre, for their technical assistance in the field and laboratory analyses of the groundplots and to Paul Sanborn, University of Northern British Columbia, for conducting the soil profile analysis.

Edited by: P. Stoy 
The works published in this journal are distributed under the Creative Commons Attribution 3.0 License. This license does not affect the Crown copyright work, which is re-usable under the Open Government Licence (OGL). The Creative Commons Attribution 3.0 License and the OGL are interoperable and do not conflict with, reduce or limit each other.

C) Crown copyright 2013

\section{References}

Amiro, B.: Estimating annual carbon dioxide eddy fluxes using open-path analysers for cold forest sites, Agr. Forest Meteorol., 150, 1366-1372, 2010.

Amiro, B. D., Barr, A. G., Barr, J. G., Black, T. A., Bracho, R., Brown, M., Chen, J., Clark, K. L., Davis K. J., Desai, A. R., Dore, S., Engel, V., Fuentes, J. D., Goldstein, A. H., Goulden, M. L., Kolb, T. E., Lavigne, M. B., Law, B. E., Margolis, H. A., Martin, T., McCaughey, J. H., Misson, L., Montes-Helu, M., Noormets, A., Randerson, J. T., Starr, G., and Xiao, J.: Ecosystem carbon dioxide fluxes after disturbance in forests of North America, J. Geophys. Res., 115, G00K02, doi:10.1029/2010JG001390, 2010.

Baldocchi, D. D.: Assessing the eddy covariance technique for evaluating carbon dioxide exchange rates of ecosystems: past, present and future, Global Change Biol., 9, 479-492, 2003.

Barr, A. G., Black, T. A., Hogg, E. H., Kljun, N., Morgenstern, K., and Nesic, Z.: Inter-annual variability in the leaf area index of a boreal aspen-hazelnut forest in relation to net ecosystem production, Agr. Forest Meteorol., 126, 237-255, 2004.

Barr, A. G., Black, T. A., Hogg, E. H., Griffis, T. J., Morgenstern, K., Kljun, N., Theede, A., and Nesic, Z.: Climatic controls on the carbon and water balances of a boreal aspen forest, 1994-2003, Glob. Change Biol., 13, 561-576, 2007.

Bogdanski, B., Sun, L., Peter, B., and Stennes, B.: Markets for forest products following large disturbance: Opportunities and challenges from the mountain pine beetle outbreak in western Canada, Natural Resources Canada, Canadian Forest Service, Pacific Forestry Centre, Information Report BC-X-429, 2011.

Bonneville, M., Strachan, I. B., Humphreys, E. R., and Roulet, N. T.: Net ecosystem $\mathrm{CO}_{2}$ exchange in a temperate cattail marsh in relation to biophysical properties, Agr. Forest Meteorol., 148, 69-81, 2008.

Bowler, R., Fredeen, A. L., Brown, M., and Black, T. A.: Residual vegetation importance to net $\mathrm{CO}_{2}$ uptake in pinedominated stands following mountain pine beetle attack in British Columbia, Canada, Forest Ecol. Manag., 269, 82-91, 2012.

Bowling, D. R., Bethers-Marchetti, S., Lunch, C. K., Grote, E. E., and Belnap, J.: Carbon, water, and energy fluxes in semiarid cold desert grassland during and following multiyear drought, J. Geophys. Res., 115, doi:10.1029/2010JG001322, 2010.

British Columbia Ministry of Forests, Lands and Natural Resource Operations: Facts about B.C.'s mountain pine beetle, http://www.for.gov.bc.ca/hfp/mountain_pine_beetle/ Updated-Beetle-Facts_May2012.pdf, 2012.

Brown, M., Black, T. A., Nesic, Z., Foord, V. N., Spittlehouse, D. L., Fredeen, A. L., Grant, N. J., Burton, P. J., and Trofymow, J. A.: Impact of mountain pine beetle on the net ecosystem produc- tion of lodgepole pine stands in British Columbia, Agr. Forest Meteorol., 150, 254-264, 2010.

Brown, M., Black, T. A., Nesic, Z., Fredeen, A. L., Foord, V. N., Spittlehouse, D. L., Bowler, R., Burton, P. J., Trofymow, J. A., Grant, N. J., and Lessard, D.: The carbon balance of two lodgepole pine stands recovering from mountain pine beetle attack in British Columbia, Agr. Forest Meteorol., 153, 82-93, 2012.

Brown, M. G., Black, T.A., Nesic, Z., Foord, V. N., Spittlehouse, D. L., Fredeen, A. L., Bowler, R., Grant, N. J., Burton, P.J., Trofymow, J. A., Lessard, D., and Meyer, G.: Evapotranspiration and canopy characteristics of two lodgepole pine stands following mountain pine beetle attack, Hydrol. Process., doi:10.1002/hyp.9870, 2013.

Burba, G. G., McDermitt, D. K., Grelle, A., Anderson, D. J., and $\mathrm{Xu}, \mathrm{L} .:$ Addressing the influence of instrument surface heat exchange on the measurements of $\mathrm{CO}_{2}$ flux from open-path gas analyzers, Global Change Biol., 14, 1854-1876, 2008.

Burton, P. J.: Restoration of forests attacked by mountain pine beetle: Misnomer, misdirected or must-do? BC J. Ecosys. Manag., 7, 1-10, 2006.

Campbell, J., Alberti, G., Martin, J., and Law, B.: Carbon dynamics of a ponderosa pine plantation following a thinning treatment in the northern Sierra Nevada, Forest Ecol. Manag., 257, 453-463, 2009.

Carroll, A. L., Regniere, J., Logan, J. A., Taylor, S. W., Bentz, B. J., and Powell, J. A.: Impacts of climate change on range expansion by the mountain pine beetle, Natural Resources Canada, Canadian Forest Service, Pacific Forestry Centre, Mountain Pine Beetle Initiative Working Paper 2006-14, 2006.

Chen, J. M., Govind, A., Sonnentag, O., Zhang Y., Barr, A., and Amiro, B.: Leaf area index measurements at Fluxnet-Canada forest sites, Agr. Forest Meteorol., 140, 257-268, 2006.

Coates K. D., DeLong, C., Burton, P. J., and Sachs, D. L.: Abundance of secondary structure in lodgepole pine stands affected by the mountain pine beetle, Report for the Chief Forester, May 2006, Bulkley Valley Centre for Natural Resources Research and Management, Smithers, BC, Canada, 17 pp., 2006.

Dilustro, J. J., Collins, B., Duncan, L., and Crawford, C.: Moisture and soil texture effects on soil $\mathrm{CO}_{2}$ efflux components in southeastern mixed pine forests, Forest Ecol. Manag., 204, 8797, 2005.

Dore, S., Kolb, T. E., Montes-Helu, M., Eckert, S. E., Sullivan, B. W., Hungate, B. A., Kaye, J. P., Hart, S. C., Koch, G. W., and Finkral, A.: Carbon and water fluxes from ponderosa pine forests disturbed by wildfire and thinning, Ecol. Appl., 20, 663-683, 2010.

Edburg, S. L., Hicke, J. A., Lawrence, D. M., and Thornton, P. E.: Simulating coupled carbon and nitrogen dynamics following mountain pine beetle outbreaks in the western United States, J. Geophys. Res., 116, G04033, doi:10.1029/2011JG001786, 2011.

Giasson, M.-A., Coursolle, C., and Margolis, H. A.: Ecosystemlevel $\mathrm{CO}_{2}$ fluxes from a boreal cutover in eastern Canada before and after scarification, Agr. Forest Meteorol., 140, 23-40, 2006.

IPCC: Climate change 2007: synthesis report, in: Core Writing Team, edited by: Pachauri, R. K. and Reisinger, A., Contribution of Working Groups I, II and III to the Fourth Assessment Report of the Intergovernmental Panel on Climate Change, IPCC, Geneva, Switzerland, 104 pp., 2007. 
Jassal, R. S., Black, T. A., Cai, T., Morgenstern, K., Li, Z., Gaumont-Guay, D., and Nesic, Z.: Components of ecosystem respiration and an estimate of net primary productivity of an intermediate-aged Douglas-fir stand, Agr. Forest Meteorol., 144, 44-57, 2007.

Krishnan, P., Black, T. A., Grant, N. J., Barr, A. G., Hogg, E. T. H., Jassal, R. S., and Morgenstern, K.: Impact of changing soil moisture distribution on net ecosystem productivity of a boreal aspen forest during and following drought, Agr. Forest Meteorol., 139, 208-223, 2006.

Kurz, W. A. and Apps, M. J.: A 70-year retrospective analysis of carbon fluxes in the Canadian forest sector, Ecol. Appl., 9, 526547, 1999.

Kurz, W. A., Dymond, C. C., Stinson, G., Rampley, G. J., Neilson, E. T., Carroll, A. L., Ebata, T., and Safranyik, L.: Mountain pine beetle and forest carbon feedback to climate change, Nature, 452, 987-990, 2008.

Lafleur, P. M. and Humphreys, E. R.: Spring warming and carbon dioxide exchange over low Arctic tundra in central Canada, Glob. Change Biol., 14, 740-756, 2007.

Meidinger, D. V. and Pojar, J.: Ecosystems of British Columbia, Special report series No. 6, Ministry of Forests, Victoria, BC, 1991.

Misson, L., Tang, J., Xub, M., McKaya, M., and Goldstein, A.: Influences of recovery from clear-cut, climate variability, and thinning on the carbon balance of a young ponderosa pine plantation, Agr. Forest Meteorol., 130, 207-222, 2005.

Mkhabela, M. S., Amiro, B. D., Barr, A. G., Black, T. A., Hawthorne, I., Kidston, J., McCaughey, J. H., Orchansky, A. L., Nesic, Z., Sass, A., Shashkov, A., and Zha, T.: Comparison of carbon dynamics and water use efficiency following fire and harvesting in Canadian boreal forests, Agr. Forest Meteorol., 149, 783-794, 2009.

Moore, R. D., Spittlehouse, D. L., Whitfield, P. H. and Stahl, K.: Chapter 3: weather and climate, in: Compendium of forest hydrology and geomorphology in British Columbia, edited by: Pike, R. G., Redding, T. E., Moore, R. D., Winkler, R. D., and Bladon, K. D., BC Ministry of Forests and Range, Research Branch, Victoria, BC and FORREX Forest Research Extension Partnership, Kamloops, BC, 2010.

Morgenstern, K., Black T. A., Humphreys, E. R., Griffis, T. J., Drewitt, G. B., Cai, T., Nesic, Z., Spittlehouse, D. L., and Livingston, N. J.: Sensitivity and uncertainty of the carbon balance of a pacific northwest Douglas-fir forest during an El Niño/La Niña cycle, Agr. Forest Meteorol., 123, 201-219, 2004.

NFI: Canada's National Forest Inventory - Ground Sampling Guidelines, https://nfi.nfis.org/documentation/ground_plot/ Gp_guidelines_v4.1.pdf, 2008.

Nishio, G.: Harvesting mountain pine beetle-killed pine while protecting the secondary structure: trials to support a partial harvesting strategy for addressing the mid-term timber supply, FPInnovations FERIC, Advantage Rep., 11, 2009.

Nishio, G.: Harvesting mountain pine beetle-killed pine while protecting the secondary structure: a comparison of partial harvesting and clearcutting methods, FPInnovations FERIC, Advantage Rep., 12, 2010.

Nishio, G.: Windthrow mortality following a partial harvest of a mountain pine beetle-attacked stand, FPInnovations FERIC, Research Note, 2011.
Pypker T. G. and Fredeen, A. L.: Ecosystem $\mathrm{CO}_{2}$ flux over two growing seasons for a sub-boreal clearcut 5 and 6 years after harvest, Agr. Forest Meteorol., 114, 15-30, 2002.

Rodenhuis, D, Bennett, K. E., Werner, A. T., Murdock, T. Q., and Bronaugh, D.: Climate overview 2007: Hydro-climatology and future climate impacts in British Columbia, Pacific Climate Impacts Consortium, University of Victoria, Victoria, BC, 2009.

Saunders, M., Tobin, B., Black, K., Gioria, M., Nieuwenhuis, M., and Osborne, B. A.: Thinning effects on the net ecosystem carbon exchange of a Sitka spruce forest are temperature-dependent, Agr. Forest Meteorol., 157, 1-10, 2012.

Safranyik, L. and Wilson, B.: The mountain pine beetle: A synthesis of biology, management, and impacts on lodgepole pine, Natural Resources Canada, Canadian Forest Service, Pacific Forestry Centre, Victoria, BC, 2006.

Snetsinger, J.: Prince George timber supply area: Rationale for allowable annual cut (AAC) determination, BC Ministry of Forests, Lands and Natural Resource Operations, 2011.

Tanner, C. B. and Thurtell, G. W.: Anemoclinometer Measurements of Reynolds Stress and Heat Transport in the Atmospheric Boundary Layer, Research and Development Technical Report ECOM-66-G22F, University of Wisconsin, Madison, Wisconsin, 1969.

Taylor, S. W. and Carroll, A. L.: Disturbance, forest age, and mountain pine beetle outbreak dynamics in BC: A historical perspective, in: Mountain pine beetle symposium: Challenges and solutions, edited by: Shore, T., Brooks, J., and Stone, J., 30-31 October 2003, Kelowna, BC, Canada, Natural Resources Canada, Canadian Forest Service, Pacific Forestry Centre, Victoria, British Columbia, Information Report BC-X-399, 41-51, 2004.

Taylor, A. R., Wang, J. R., and Kurz, W.: Effects of harvesting intensity on carbon stocks in eastern Canadian red spruce (Picea rubens) forests: An exploratory analysis using the CBM-CFS3 simulation model, Forest Ecol. Manag., 255, 3632-3641, 2008.

Vesala, T., Suni, T., Rannik, U., Keronen, P., Markkanen, T., Sevanto, S., Gronholm, T., Smolander, S., Kulmala, M., Ilvesniemi, H., Ojansuu, R., Uotila, A., Levula, J., Makela, A., Pumpanen, J., Kolari, P., Kulmala, L., Altimir, N., Berninger, F., Nikinmaa, E., and Hari, P.: Effect of thinning on surface fluxes in a boreal forest, Global Biogeochem. Cy., 19, GB2001, doi:10.1029/2004GB002316, 2005.

Walton, A.: Update of the infestation projection based on the Provincial Aerial Overview Surveys of Forest Health conducted from 1999 through 2011 and the BCMPB model (year 9), BC Ministry of Forests, Lands and Natural Resource Operations Provincial Level Projection of the Current Mountain Pine Beetle Outbreak, http://www.for.gov.bc.ca/ftp/hre/external/!publish/ web/bcmpb/year9/BCMPB.v9.2012Kill.pdf, 2012.

Webb, E. K., Pearman, G. I., and Leuning, R.: Correction of flux measurements for density effects due to heat and water vapour transfer, Quart. J. R. Meteorol. Soc., 106, 85-100, 1980.

Wesely, M. L. and Hart, R. L.: Variability of short term eddy-correlation estimates of mass exchange, in: The ForestAtmosphere Interaction, edited by: Hutchinson, B. A. and Hicks, B. B., D. Reidel, Dortrecht, 591-612, 1985.

Wohlfahrt, G., Fenstermaker, L. F., and Arnone, J. A.: Large annual net ecosystem $\mathrm{CO}_{2}$ uptake of a Mojave Desert ecosystem, Glob. Change Biol., 14, 1475-1487, 2008. 